\title{
A mintaadó népegészségügyi rendszerek elemzéséből levonható tanulságok és következtetések
}

\author{
Conclusions and lessons learned through the examples of international \\ public health systems
}

\author{
Szerzők: Túri Gergő $₫$, Földesi Judit, ${ }^{a, b}$ Horváth Krisztián, ${ }^{a, c}$ Varsányi Péter ${ }^{a}$ \\ a: Országos Közegészségügyi Intézet, b: Eötvös Loránd Tudományegyetem, \\ c: Budapesti Corvinus Egyetem
}

Beküldve: 2018. 03. 28.

doi: $10.24365 /$ ef.v59i2.267

Összefoglaló: A cikk célja a különszámban ismertetett, mintaadó népegészségügyi rendszerek példáiból levonható tapasztalatok és tanulságok megfogalmazása, valamint ezek alapján a magyar egészségfejlesztési hálózat és népegészségügyi rendszer lehetséges továbbfejlesztési irányainak azonosítása.

Kulcsszavak: népegészségügyi rendszer; egészségfejlesztési hálózat; Magyarország

Summary: The purpose of this article is to introduce experiences and lessons learned through the examples of international public health systems, introduced in the special issue, and to identify the possible directions for further development of the Hungarian health promotion network and public health system.

Keywords: public health system; health promotion network; Hungary

\section{A BEMUTATOTT ORSZÁGOK ÖSSZEHASONLÍ- TÁSA TíZ ALAPVETŐ NÉPEGÉSZSÉGÜGYI FELADAT ELLÁTÁSA SZEMSZÖGÉBŐL}

Az Egészségügyi Világszervezet (World Health Organization) tíz alapvető népegészségügyi feladatot (ANEF) fogalmazott meg, amelyek megvalósítása alapfeltétele egy hatékonyan múködő népegészségügyi rendszernek. ${ }^{1}$ A 10 alapfeladat három fö kategóriára bontható: 1. Információ előállítása a népegészségügyi elemzésekhez; 2 . Szolgáltatások nyújtása; 3. Támogató tevékenységek megvalósítása [1. ábra].

A különszámunkban bemutatott hét nemzetközi példa (Amerikai Egyesült Államok, Anglia, Kanada,
Hollandia, Olaszország, Norvégia, Új-Zéland), valamint Magyarország népegészségügyi rendszerét aszerint hasonlítottuk össze, hogy a vizsgált országokban múködő szervezetek a tíz alapvető népegészségügyi feladat közül melyeket látják el [1. táblázat és 2. táblázat].

A táblázat oszlopaiban a vizsgált országok, soraiban az alapvető népegészségügyi feladatokat ellátó szervezetek vannak felsorolva. A piros színnel jelölt szervezetek országos, a kék színnel jelölt szervezetek regionális, míg a zöld színnel jelölt szervezetek közösségi szinten múködnek. A táblázat értelmezéséhez az alábbiakban röviden ismertetjük a tíz alapfeladat tartalmát. 


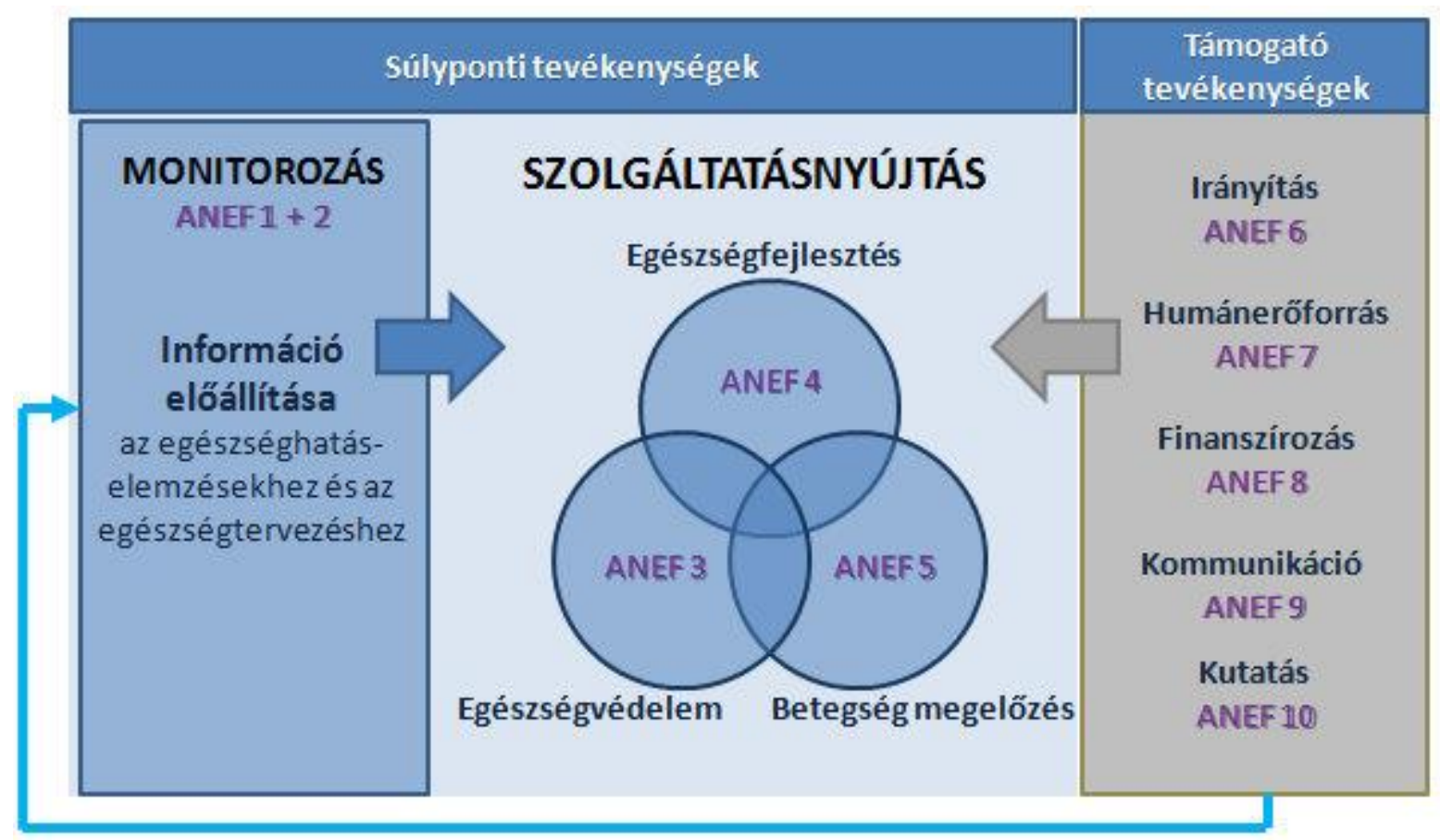

Forrás: $\mathrm{WHO}^{1}$

Információ-eloállítás

\section{ANEF1}

A lakosság egészségének és jóllétének monitorozása. Ez a feladat magában foglalja többek között egy, a lakosság egészségét különböző mutatók alapján monitorozni képes rendszer kiépítését és múködtetését, a gyűjtött adatok trendelemzését, az egészségegyenlőtlenségek detektálását, a lakosság szükségleteinek azonosítását és az adatokon alapuló beavatkozástervezést is.

\section{ANEF2}

Egészségkockázatok és vészhelyzetek monitorozása és kezelése. Ez a feladat magában foglalja a biológiai, kémiai és fizikai egészségkockázatok azonosítását és monitorozását kiemelten a munkahelyeken és az épített környezetben, a környezet-egészségügyi kockázatok elemzését és kezelését, a lakosság megfelelő tájékoztatását és a veszélyek csökkenté- sét célzó beavatkozások tervezését és megvalósítását. Ide tartoznak még az egészségügyi vészhelyzetek menedzselésével kapcsolatos feladatok és az azokhoz szükséges adatgyújtési és monitorozási tevékenységek is.

\section{Szolgáltatásnyújtás}

\section{ANEF3}

Egészségvédelem, beleértve a környezet- és foglalkozás-egészségügyet, valamint az élelmiszer-biztonságot is. Ez a feladat többek között magában foglalja a környezeti, munkahelyi és élelmiszer-biztonsághoz szükséges kockázatértékeléseket és intézkedéseket, amelyek leggyakrabban az ezekre a célokra kijelölt hatóságok feladatai. A feladat célozza a lakosság egészségének védelméhez szükséges szabályozást, a meglévő rendeletek ellenőrzési hátterét és az egészséges környezet megteremtését szolgáló új jogszabályok kidolgozásának intézményi hátterét is. 


\section{ANEF4}

Egészségfejlesztés, beleértve az egészséget befolyásoló tényezőket és az egészségegyenlötlenségeket. Ez a feladat magában foglalja többek között annak elősegítését, hogy az egyén vagy közösség egészség-magatartása, környezete egészségesebb irányba változzon, ezenkívül az egészségkultúra pozitív irányú befolyásolását és az egészségkommunikáció fejlesztését. A feladat része továbbá a hatékony egészség-magatartás kialakításához szükséges interszektorális együttmúködés létrehozása, az egészségszolgáltatások átalakítása, azaz azok a tevékenységek, amelyek hozzásegíthetik az egyént vagy a közösséget, hogy javítsák egészségüket és az egészségüket befolyásoló tényezőket, valamint csökkentsék a környezetükben lévő egészségegyenlőtlenségeket.

\section{ANEF5}

Betegségmegelőzés, beleértve a betegségek korai felismerését. A betegségmegelőzésnek egyaránt irányulnia kell a fertőző és a nem fertőző betegségekre. Az elsődleges megelőzési feladatok közé tartoznak többek között a védőoltások, az egészségkockázatokról szóló tájékoztatások, az egyéni vagy közösségi szinten ható, kockázatcsökkentő beavatkozások. Másodlagos megelőzési feladat például a betegségek korai felismerésére irányuló, bizonyítékokon alapuló szűrőprogramok szervezése (beleértve a veleszületett rendellenességek szűrését is), vagy az ezekhez szükséges eszközök beszerzése.

\section{Támogató tevékenységek}

\section{ANEF6}

Irányitás az egészség és a jóllét biztositása érdekében. Ez a feladat biztosítja a népegészségüggyel kapcsolatos információkat a szakpolitikai fejlesztések folyamatában, ahol belső és külső döntéshozók bevonásával határoznak meg jövőképet, küldetést, mérhető egészségügyi célokat és népegészségügyi tevékenységeket nemzeti, regionális és helyi szinten, sokszor nemzetközi ajánlások adaptálásával.
ANEF7

Elegendő és kompetens népegészségügyi szakember biztositása. Ez a feladat biztosítja a megfelelő oktatást, képzést és továbbképzést a népegészségügyi szakemberek számára. A megfelelő népegészségügyi rendszer kialakításának előfeltétele az elegendő számú, kompetens szakember biztosítása, de a képzések nem érhetnek véget egy szakképesítés megszerzésével, folyamatos továbbképzés szükséges a népegészségügyi rendszer minőségének megtartása, javítása, valamint az új kihívások kezelése érdekében.

\section{ANEF8}

Fenntartható szervezeti struktúra és finanszírozás biztositása. Ez a feladat magában foglalja többek között a népegészségügyi rendszer múködéséhez szükséges szervezeti struktúra, valamint az annak fenntartásához és múködéséhez szükséges finanszírozás és minőségbiztosítás nyújtását. A finanszírozás célja, a megfelelő pénzügyi háttér és ösztönzők biztosítása a szolgáltatók számára, hogy minden személy hozzáférhessen a népegészségügyi ellátásokhoz. A minőségbiztosítás során olyan normákat dolgoznak ki, amelyek biztosítják a személyes és közösségi népegészségügyi szolgáltatások minőségét a betegségmegelőzés, az egészségfejlesztés és az ezeken a normákon alapuló szolgáltatások értékelésénél.

\section{ANEF9}

Érdekképviseleti kommunikáció és társadalmi mozgósitás az egészségért. E feladat célja többek között az, hogy megfelelő egészségkommunikációval fejlesszük az egyének egészségértését, valamint hatásos információátadással motiváljuk, befolyásoljuk az egyéneket, intézményeket, lakossági csoportokat a fontosabb, egészséggel kapcsolatos témákban. Az egészségkommunikáció többféle területet is magában foglal (pl. szakújságírás, oktatás, szervezeti kommunikáció, kockázati és válságkommunikáció, szociális marketing) és többféle csatornán (pl. interperszonális kommunikáció, rádió, TV, újság, blog, online fórumok) is történhet. 


\section{ANEF10}

Népegészségügyi kutatások fejlesztése a döntéshozók és a szakemberek tájékoztatása céljából. Ez a feladat magában foglalja többek között új kutatási módszerek és innovatív technológiák kidolgozását a népegészségügyben, olyan kutatások fejlesztését, amelyek a bizonyítékokon alapuló politikai döntéshozatalt támogatják, valamint a kutatóközpontokkal és a tudományos intézményekkel való együttműködések kialakítását a szakpolitikai döntéshozatal támogatásához.

\section{ÁLTALÁNOS TAPASZTALATOK}

A jelen különszámban vizsgált fejlett országokban többszintű - a közigazgatási rendszerhez illeszkedő - feladatmegosztáson alapuló rendszerek alakultak ki. Az egyes múködési szinteken számos szervezet és szereplő tevékenykedik, különböző funkciókat látnak el, azonban tevékenységeiket összehangoltan végzik. Fontos általános tapasztalat továbbá a hálózatos múködési forma, melynek során az azonos múködési szintek szervezetei és/vagy a különböző múködési szintek szervezetei hálózatokba tömörülnek, partnerségeket és együttmúködéseket alakítanak ki. A hálózatok és együttmúködések kialakításának számos célja lehet: közös ismeret- és tudásfejlesztés, a tudás, az információ és az erőforrások megosztása, továbbá a tevékenységek és szolgáltatások koordinálása és összehangolása, közös tervezés, érdekképviselet.

Univerzálisan jellemző, hogy számos népegészségügyi kutatóműhely múködik a vizsgált országokban, amelyek bekapcsolódnak a nemzetközi kutatói térbe is, hozzájárulva, hogy az országukban végrehajtott egészségfejlesztési tevékenységek naprakész, bizonyítékokkal alátámasztott módszereken alapuljanak. A kutatómúhelyek továbbá alapvető szerepet töltenek be az országon belüli tudás- és információmegosztásban, valamint a szolgáltatási standardok, irányelvek kialakításában. A vizsgált fejlett országok nagy hangsúlyt fektetnek a széles körû adatgyűjtési rendszerek kialakítására és múködtetésére, felismerve, hogy hatékony és eredményes beavatkozások megtervezésére, megvalósítására és értékelésére csak akkor van esély, ha megfelelő minőségű adatok állnak rendelkezésre az elemzésekhez.

\section{ORSZÁGOS SZINTRE VONATKOZÓ MEGÁLLAPÍTÁSOK}

Országos szinten számos kutatóintézet, egyetem, kormányzati háttérintézmény és független szervezet végez módszertanfejlesztést, programalkotást az egészségfejlesztés területén. Ezen a szinten található a legtöbb esetben a népegészségügyi rendszer szakmai irányítása és koordinálása. Az országos szinten múködő szervezetek feladata a rendszer egyes szereplőinek monitorozása, finanszírozása is. Ugyancsak számos példa található arra vonatkozóan, hogy országos szinten működő szervezetek fogalmaznak meg az egészségszolgáltatások nyújtására vonatkozó szakmai irányelveket, útmutatásokat vagy standardokat. Az országos szinten lévő szervezetek gyakran vesznek részt a szakmapolitikai javaslatok és stratégiák kialakításában, valamint tanácsokat adnak különböző kormányzati szereplőknek.

\section{REGIONÁLIS SZINTRE VONATKOZÓ MEGÁLLAPÍTÁSOK}

Regionális szinten ugyancsak több szervezet és szereplő lát el kulcsfontosságú feladatokat az adott ország népegészségügyi rendszerében. Fontos elem a középirányítói funkció betöltése, az adott területen múködő egészségszolgáltatók tevékenységeinek tervezése, szervezése és koordinálása, egyes esetekben a közösségi szolgáltatók finanszírozása. A regionális szinten múködő szervezetek között is találunk olyat, amely szolgáltatási irányelveket, standardokat fogalmaz meg, amelyek betartását is ellenőrzi. E szervezetek gyakran fontos szerepet töltenek be az országos szint felől a közösségi szint felé, valamint a közösségi szint felől az országos szint felé irányuló információ- és tudásmegosztás elősegítésében, az országos szinten működő szervezetek által kialakított, bizonyítottan hatásos programok helyi szintre adaptálásában.

\section{KÖZÖSSÉGI SZINTRE VONATKOZÓ MEGÁLLAPÍTÁSOK}

Közösségi szinten a lakóhelyközeli egészségszolgáltatások biztosítását számos szervezet együttmúködésben látja el minden országban. Egyes esetekben 
a szolgáltatások szervezésére létrehoznak egy szervezetet, míg más esetekben e feladatért a regionális szinten múködő szereplő a felelős. A közösségi egészségszolgáltatók partnerségeket alakítanak ki annak érdekében, hogy összehangolják szolgáltatásaikat. Számos esetben készítenek stratégiai, illetve közösségi egészségtervet. A közösségi szinten múködő szervezetek gyakran látnak el még érdekképviseleti, érzékenyítési és mozgósítási feladatokat is.

\section{A NEMZETKÖZI PÉLDÁK ALAPJÁN MEGFOGALMAZHATÓ TANULSÁGOK ÉS KÖVETKEZTETÉSEK}

\section{A monitorozási kapacitások fejlesztése és a tevékenységek összehangolása}

A vizsgált országok népegészségügyi rendszerében számos olyan szervezet múködik országos, regionális, valamint közösségi szinten is, amelynek feladata a lakosság egészségének és jóllétének monitorozása, valamint az egészségkockázatok és vészhelyzetek figyelemmel követése, kezelése. A magyar népegészségügyi rendszer szempontjából célszerünek tûnik az információ-előállítással foglalkozó szervezetek számának, humán erőforrásának fejlesztése, valamint tevékenységeik rendszerszintű összehangolása. A hazai monitorozási rendszer fejlesztése lehetővé tenné, hogy szélesebb körben lehessen megvalósítani a közösségi szükségletek és igények azonosítását, elemzését, valamint a beavatkozások hatásainak nyomon követését, értékelését.

\section{Hálózatos múködési modell kialakítása}

A nemzetközi példák elemzése alapján célszerűnek látszik egy több szintű, feladatmegosztáson alapuló egészségfejlesztési struktúra kialakítása. Olyan hálózatos múködési modell kialakítása ajánlható, amely elősegíti a hatékony tudásmenedzsmentet, támogatja a bizonyítékokon alapuló szolgáltatások fejlesztését és megosztását a hálózat szervezetei között. E hálózatos múködés várható haszna, hogy elősegíti a különböző ágazatok szervezeteinek tevékenységeik összehangolását, valamint az interszektoriális együttmúködések és programok helyi igények szerinti megvalósítását.
A lakosságszámhoz illeszkedő, rugalmas működési struktúra kialakítása

Az amerikai egyesült államok-beli helyi egészségosztályok példája alapján célszerúnek látszik az, hogy a közösségi szinten tevékenykedő népegészségügyi szervezet egy viszonylag rugalmas múködési struktúrát alakítson ki, ahol a szervezet humánerőforrásösszetétele, létszáma és biztosított szolgáltatásai a hozzá tartozó területen élő lakosság számával arányos. E múködés várható haszna, hogy a népegészségügyi szervezet a helyi igényekhez és szükségletekhez igazodó szolgáltatási portfóliót alakithat ki.

\section{Közösségi egészségtervek készítése és megvalósítása}

Valamennyi vizsgált országban létezik olyan közösségi vagy regionális szervezet, amelynek feladata egészségtervek készítése és az abban foglalt beavatkozások megvalósítása, szervezése, koordinálása: Angliában az egészség- és jólléttestületek, az Amerikai Egyesült Államokban a helyi egészségosztályok, Hollandiában és Norvégiában a helyi önkormányzatok, Kanadában a népegészségügyi egységek, Olaszországban a regionális egészségügyi hivatalok, Új-Zélandon pedig a körzeti egészségbizottságok feladata. Az egészségtervezés várható haszna, hogy a közösségi szükségletekre reagáló, bizonyítottan hatásos, ezáltal a közösségi erőforrásokat hatékonyan felhasználó programok és akciók valósíthatók meg a lakosság aktív bevonásával és a közösségi szereplők együttmúködésével.

\section{Szolgáltatási standardok, irányelvek kialakítása}

Az Amerikai Egyesült Államokban országos szinten működő Megyei és Városi Egészség-tisztviselők Nemzeti Szövetségének, valamint a Kanadában tartományi szinten múködő Egészségügyi Minisztériumnak feladata az egészségszolgáltatásokhoz kapcsolódó standardok, irányelvek és útmutatások megfogalmazása, a standardok szerinti múködés szakmai támogatása és a kritériumok betartásának ellenőrzése. A tapasztalatok alapján érdemes megfontolni hazánkban is a népegészségügyi szolgáltatásokhoz kapcsolódó standardok, irányelvek kialakításáért felelős szervezet megalakítását. 
Az egységes irányelvek szerinti szolgáltatásnyújtás várható haszna, hogy csökken a szolgáltatások minősége közötti különbség a területi egységek között, valamint biztosítható, hogy evidenciákon alapuló, hatásos szolgáltatásokat kapjon a lakosság.

További szereplők bevonása a döntéshozatali folyamatokba

A vizsgált országok népegészségügyi rendszerében számos szereplő vesz részt az irányítással, szakmai támogatással és koordinációval kapcsolatos feladatok ellátásában a különböző múködési szinteken. A döntéshozatal folyamatába szakmai és civil szervezetek egyaránt bekapcsolódnak. Célszerű lehet olyan munkamegosztás kialakítása a hazai népegészségügyi rendszer szereplői között is, amelynek során országos, megyei és közösségi szinten további szereplők kerülnek bevonásra ezeknek a feladatoknak az ellátására. A további szereplők bevonásának várható haszna, hogy bővül a feladatok ellátásáért felelős és ezért együttmúködésre ösztönzött szervezetek köre, valamint biztositható a szektorokon átnyúló népegészségügyi szemlélet megerősítése.

\section{Középirányítói funkció fejlesztése}

Számos ország népegészségügyi rendszerében azonosítható regionális szinten középirányítói funkciókat ellátó szervezet, amelyet a hazai népegészségügyi rendszerben is célszerű lehet kialakítani. A funkció megjelenésének várható haszna, hogy általa biztosítható az országos és közösségi szintek szervezetei közötti kétirányú információáramlás, a több közösséget érintő programok és beavatkozások összehangolása, szervezése.

\section{Specializálódott kutatóhelyek kialakítása}

Valamennyi vizsgált ország esetében megfigyelhető, hogy számos szak- és problématerületen múködik specifikus kutatási szervezet (pl. az Ameri- kai Egyesült Államokban múködő nemzeti egészségügyi intézetek, a holland Egészségeséletmódközpont, a Norvégiában múködő Egészségszolgáltatások Tudásközpontja). A meghatározott szakterületekre specializálódott kutatóintézetek és múhelyek kialakításának várható haszna, hogy e szervezetek hatékonyabban tudnak eredményes népegészségügyi beavatkozásokat és módszereket fejleszteni. A hazai kutatóhelyek számának és kapacitásainak növelésével, a kutatások összehangolásával és koordinálásával továbbá fejleszthető a bizonyítékokon alapuló döntéshozatal.

\section{A szakemberképzés összehangolása}

Az áttekintett országpéldáknál a kutatóintézetek mellett a népegészségügyi szakemberek képzését végző egyetemek szakosodása, egyfajta spontán feladatmegosztás is megfigyelhető. A nemzetközi tapasztalatok azt mutatják, hogy sokféle új szakterület kerül az oktatási intézmények fókuszába (pl. a globalizáció hatása az egészségre, viselkedésváltoztatás). Célszerű megvizsgálni, hogy hazánkban milyen lehetőségek adódhatnak a szakemberképzés, a képzési portfóliók és tananyagok összehangolása érdekében.

\section{A népegészségügyi szolgáltatók bevonása a humán erőforrás fejlesztésébe}

A vizsgált népegészségügyi rendszereknél az egyetemek és szakmai szervezetek mellett számos térségi és közösségi szolgáltató kapcsolódik be a népegészségügyi szakemberek képzésébe (pl. az Új-Zélandon múködő regionális népegészségügyi szolgáltatók, vagy a kanadai British Columbia tartományban múködő regionális egészséghatóságok). A hazai népegészségügyi szakemberek képzésének fejlesztése érdekében célszerü a népegészségügyi szolgáltatók nagyobb mértékú bevonása a népegészségügyi humán erőforrás fejlesztésébe, aminek várható haszna nemcsak a szakember-utánpótlás biztosításában, hanem a szakemberek megtartásában is jelentkezhet. 
1. táblázat: A vizsgált országok szervezetei a 10 alapvető népegészségügyi feladat megvalósitása szerint kategorizálva I.

\begin{tabular}{|c|c|c|c|c|c|c|c|c|c|}
\hline \multirow{2}{*}{\multicolumn{2}{|c|}{$\begin{array}{l}\text { Alapvető népegészzég- } \\
\text { ügyi feladatok }\end{array}$}} & \multicolumn{8}{|c|}{ Vizsgált országok } \\
\hline & & Anglia & Amerikai Egyesült Államok & Hollandia & Kanada & Norvégia & Olaszország & Új-zéland & Magyarország \\
\hline 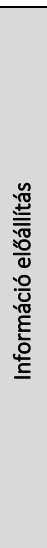 & $\begin{array}{l}\text { Monitorozás } \\
\text { (ANEF 1-2) }\end{array}$ & $\begin{array}{c}\text { Public Health England, NHS } \\
\text { England, Society for Social } \\
\text { Medicine, Association of } \\
\text { Directorate of Public He- } \\
\text { alth, Care Quality Commis- } \\
\text { sion, National Institute of } \\
\text { Care Excellence, Faculty of } \\
\text { Public Health, } \\
\text { Public Health England, } \\
\text { Local goverments, Local he- } \\
\text { alth protection teams }\end{array}$ & $\begin{array}{c}\text { Center for Disease Control } \\
\text { an Prevention, Center for } \\
\text { Disease Control an Pre- } \\
\text { vention - Office of Public } \\
\text { Health Preparedness and } \\
\text { Response, National Center } \\
\text { for Health Statistics, Natio- } \\
\text { nal Institutes of Health Na- } \\
\text { tional, Institute of Minority } \\
\text { Health and Health Dispari- } \\
\text { ties, National Cancer Insti- } \\
\text { tute, National Center for } \\
\text { Health Statistics, National } \\
\text { Insitutes of Health, } \\
\text { Substance Abuse and } \\
\text { Mental Health Administra- } \\
\text { tion, } \\
\text { Local Health Departments }\end{array}$ & $\begin{array}{c}\text { National Institute for Public } \\
\text { Health and the Environ- } \\
\text { ment, Statistics Nether- } \\
\text { lands, Dutch Food and Con- } \\
\text { sumer Product Safety } \\
\text { Authority, Netherlands } \\
\text { Centre for Occupational } \\
\text { Diseases, } \\
\text { Community Health Services }\end{array}$ & $\begin{array}{c}\text { Statistics Canada, Canadian } \\
\text { Food Inspection Agency, } \\
\text { Canadian IIstitute for He- } \\
\text { alth Information, Canada } \\
\text { Health Infoway (orszá- } \\
\text { gos)Health Canada, Minis- } \\
\text { ter of Health, Chief Public } \\
\text { Health Officer, Public He- } \\
\text { alth Agency of Canada, Na- } \\
\text { tional Collaborating Cen- } \\
\text { ters for Public Health, Ca- } \\
\text { nadian Food Inspection } \\
\text { Agency, } \\
\text { Ministry of Public Health } \\
\text { and Long Term Care, Public } \\
\text { Health Ontario }\end{array}$ & $\begin{array}{c}\text { Norwegian Food Safety } \\
\text { Authority, National Insti- } \\
\text { tute of Occupational He- } \\
\text { alth, Norwegian Institute of } \\
\text { Public Health, Statistics } \\
\text { Norway, } \\
\text { Counnty Municipalities, } \\
\text { Local Municipalities }\end{array}$ & $\begin{array}{c}\text { National Institute of Public } \\
\text { Health Surveillance and He- } \\
\text { alth Promotion, National } \\
\text { Health Council, National } \\
\text { Institute of Public Health } \\
\text { Surveillance and Health } \\
\text { Promotion, National Centre } \\
\text { for Desease Prevention and } \\
\text { Control }\end{array}$ & $\begin{array}{l}\text { Health Research Council of } \\
\text { New Zealand, Institute of } \\
\text { Environmental Science and } \\
\text { Research Central } \\
\text { Government, Minister of } \\
\text { Health, Ministry of Health, } \\
\text { Other ministerial advisory } \\
\text { committees, Health Rese- } \\
\text { arch Council of New Ze- } \\
\text { aland }\end{array}$ & $\begin{array}{c}\text { Központi Statisztikai Hiva- } \\
\text { tal, Országos Közegészség- } \\
\text { ügyi Intézet }\end{array}$ \\
\hline 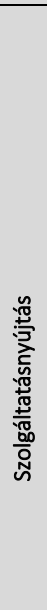 & $\begin{array}{l}\text { Egészségvéde- } \\
\text { lem (ANEF 3) }\end{array}$ & $\begin{array}{l}\text { Public Health England, NHS } \\
\text { England, Food Standard } \\
\text { Agency, Faculty of Public } \\
\text { Health, National Institute } \\
\text { of Care Excellence, } \\
\text { Public Health England, } \\
\text { Local governments, Local } \\
\text { health protection teams, } \\
\text { NHS England }\end{array}$ & $\begin{array}{c}\text { Department of Health and } \\
\text { Human Services, Office of } \\
\text { the Assistant Secretary for } \\
\text { Health, Office of Disease } \\
\text { Prevention and Health } \\
\text { Promotion, US Preventive } \\
\text { Task Force, National Pre- } \\
\text { vention Council, Prevention } \\
\text { Advisory Group, Center for } \\
\text { Disease Control an Pre- } \\
\text { vention - Office for State, } \\
\text { Tribal, Local, and Territorial } \\
\text { Support, National Institutes } \\
\text { of Health, Food and Drug } \\
\text { Administration, Substance } \\
\text { Abuse and Mental Health } \\
\text { Services Administration, } \\
\text { State Governments, State } \\
\text { Health Departments, } \\
\text { Local Health Departments }\end{array}$ & $\begin{array}{c}\text { Ministry of Health, Welfare } \\
\text { and Sport, Ministry of Infra- } \\
\text { structure and the Environ- } \\
\text { ment, Ministry of Educa- } \\
\text { tion } \\
\text { Ministry of Social Welfare } \\
\text { and Employment, Ministry } \\
\text { of Economic Affairs, Natio- } \\
\text { nal Institute for Public He- } \\
\text { alth and the Environment, } \\
\text { Dutch Food and Consumer } \\
\text { Product Safety Authority, } \\
\text { Netherlands, Centre for Oc- } \\
\text { cupational Diseases, Net- } \\
\text { herlands Environmental As- } \\
\text { sessment Agengcy, Com- } \\
\text { munity Health Services }\end{array}$ & $\begin{array}{c}\text { Health Canada, Public He- } \\
\text { alth Agency of Canada, Ca- } \\
\text { nadian Food Inspection } \\
\text { Agency, } \\
\text { Public Health Ontario, } \\
\text { Public Health Unit }\end{array}$ & $\begin{array}{l}\text { Ministry of Health and He- } \\
\text { alth Care Serives, Norwe- } \\
\text { gian Labour Inspection } \\
\text { Authority, Norwegian Food } \\
\text { Safety Authority, Norwe- } \\
\text { gian Board of Health Super- } \\
\text { vision, Local Municipalities, } \\
\text { Health Clinics, Pregnancy } \\
\text { Clinic, Clinic for mother and } \\
\text { child, Youth Clinic, School } \\
\text { Clinic, Healthy Life Centers }\end{array}$ & $\begin{array}{l}\text { Ministry of Labour and So- } \\
\text { cial Policy, Institute for } \\
\text { Environmental Protection } \\
\text { and Research, } \\
\text { Regional Government, } \\
\text { Local Health Units }\end{array}$ & $\begin{array}{l}\text { Institute of Environmental } \\
\text { Science and Research, } \\
\text { Regional Public Health Ser- } \\
\text { vices, Voluntary services }\end{array}$ & $\begin{array}{l}\text { Emberi Erőforrások Minisz- } \\
\text { tériuma, Országos Köz- } \\
\text { egészségügyi Intézet, Me- } \\
\text { gyei Kormányhivatal, } \\
\text { Járási Kormányhivatal }\end{array}$ \\
\hline
\end{tabular}




\begin{tabular}{|c|c|c|c|c|c|c|c|c|}
\hline $\begin{array}{l}\text { Egészségfejlesz- } \\
\text { tés (ANEF 4) }\end{array}$ & $\begin{array}{c}\text { Public Health England, Fa- } \\
\text { culty of Public Health, Soci- } \\
\text { ety for Social Medicine, As- } \\
\text { sociation of Directors of } \\
\text { Public Health, Royal Society } \\
\text { of Public Health, King's } \\
\text { Fund, Food Standard } \\
\text { Agency, } \\
\text { Public Health England, } \\
\text { Local Governments, Health } \\
\text { and Wellbeing Boards }\end{array}$ & $\begin{array}{c}\text { Center for Disease Control } \\
\text { an Prevention, National } \\
\text { Institutes of Health, Food } \\
\text { and Drug Administration, } \\
\text { Substance Abuse and } \\
\text { Mental Health Services Ad- } \\
\text { ministration, National Asso- } \\
\text { ciation of County and City } \\
\text { Health Officials, } \\
\text { Local Health Department }\end{array}$ & \begin{tabular}{|c|} 
National Institute for Public \\
Health and the Environ- \\
ment, Centre for Healthy \\
Living, Dutch Association \\
for Prevention and Health \\
Promotion, Netherlands \\
Centre for Occupational \\
Diseases, Netherlands \\
Environmental Assessment \\
Agency, \\
Community Health Servi- \\
ces, Local municipalities
\end{tabular} & $\begin{array}{l}\text { Health Canada, Public He- } \\
\text { alth Agency of Canada, Ca- } \\
\text { nadian Food Inspection } \\
\text { Agency, } \\
\text { Public Health Ontario, } \\
\text { Public Health Unit }\end{array}$ & $\begin{array}{c}\text { Directorate for Health, Sta- } \\
\text { tistics Norway, National } \\
\text { Institute of Occupational } \\
\text { Health, } \\
\text { County Municipalities, } \\
\text { Local Municipalities, Health } \\
\text { Clinics, Pregnancy Clinic, } \\
\text { Clinic for mother and child, } \\
\text { Youth Clinic, School Clinic, } \\
\text { Healthy Life Centers }\end{array}$ & $\begin{array}{l}\text { Ministry of Labour and So- } \\
\text { cial Policy, Ministry of He- } \\
\text { alth, National Health Ser- } \\
\text { vice, National Institute of } \\
\text { Public Health Surveillance } \\
\text { and Health Promotion, Na- } \\
\text { tional Centre for Disease } \\
\text { Prevention and Control, } \\
\text { National Health Council, } \\
\text { Local Health Units }\end{array}$ & $\begin{array}{c}\text { Health Promotion Agency, } \\
\text { District Health Boards, Re- } \\
\text { gional Public Health Servi- } \\
\text { ces, } \\
\text { Voluntary services }\end{array}$ & $\begin{array}{l}\text { Emberi Erő́források Minisz- } \\
\text { tériuma, Egészségfejlesz- } \\
\text { tési Iroda, Járási Kormány- } \\
\text { hivatal, Védőnő, Praxis }\end{array}$ \\
\hline $\begin{array}{l}\text { Betegség meg- } \\
\text { elö́zés } \\
\text { (ANEF 5) }\end{array}$ & $\begin{array}{l}\text { Public Health England, NHS } \\
\text { England, National Institute } \\
\text { of Care Excellence, Food } \\
\text { Standard Agency, } \\
\text { Public Health England, } \\
\text { NHS England, Local } \\
\text { Governments }\end{array}$ & $\begin{array}{c}\text { Department of Health and } \\
\text { Human Services, Office of } \\
\text { the Assistant Secretary for } \\
\text { Health, Office of Disease } \\
\text { Prevention and Health } \\
\text { Promotion, US Preventive } \\
\text { Task Force, National Pre- } \\
\text { vention Council, Prevention } \\
\text { Advisory Group, Center for } \\
\text { Disease Control an Pre- } \\
\text { vention, National Institutes } \\
\text { of Health, Food and Drug } \\
\text { Administration, Substance } \\
\text { Abuse and Mental Health } \\
\text { Services Administration, } \\
\text { National Association of } \\
\text { County and City Health Of- } \\
\text { ficials } \\
\text { Local Health Departments }\end{array}$ & $\begin{array}{c}\text { National Institute for Public } \\
\text { Health and the Environ- } \\
\text { ment, Community Health } \\
\text { Services, Local municipali- } \\
\text { ties }\end{array}$ & $\begin{array}{l}\text { Health Canada, Public He- } \\
\text { alth Agency of Canada, Ca- } \\
\text { nadian Food Inspection } \\
\text { Agency, } \\
\text { Public Health Ontario, } \\
\text { Public Health Unit }\end{array}$ & $\begin{array}{l}\text { Ministry of Health and He- } \\
\text { alth Care Serives, Local } \\
\text { Municipalities, Health Cli- } \\
\text { nics, Pregnancy Clinic, Cli- } \\
\text { nic for mother and child, } \\
\text { Youth Clinic, School Clinic, } \\
\text { Healthy Life Centres }\end{array}$ & $\begin{array}{c}\text { National Centre for Dese- } \\
\text { ase Prevention and Cont- } \\
\text { rol, } \\
\text { Local health Units }\end{array}$ & $\begin{array}{c}\text { National Screening Unit, } \\
\text { District Health Boards, Re- } \\
\text { gional Health Services, } \\
\text { Public Hospitals, Rehabilita- } \\
\text { tion Services, Private Hos- } \\
\text { pitals, Pharmacies, Labo- } \\
\text { ratories, Primary Health Or- } \\
\text { ganisations, Voluntary ser- } \\
\text { vices }\end{array}$ & $\begin{array}{c}\text { Emberi Erőforrások Minisz- } \\
\text { tériuma, Országos Köz- } \\
\text { egészségügyi Intézet, } \\
\text { Egészségfejlesztési Iroda, } \\
\text { Járási Kormányhivatal, Vé- } \\
\text { dőnő, Praxis }\end{array}$ \\
\hline
\end{tabular}


2. táblázat: A vizsgált országok szervezetei a 10 alapvetô népegészségügyi feladat megvalósitása szerint kategorizálva II.

\begin{tabular}{|c|c|c|c|c|c|c|c|c|c|}
\hline \multirow{2}{*}{\multicolumn{2}{|c|}{$\begin{array}{l}\text { Alapvető népegészség- } \\
\text { ügyi feladatok }\end{array}$}} & \multicolumn{8}{|c|}{ Vizsgált országok } \\
\hline & & Anglia & Amerikai Egyesült Államok & Hollandia & Kanada & Norvégia & Olaszország & Új-zéland & Magyarország \\
\hline \multirow[t]{2}{*}{ 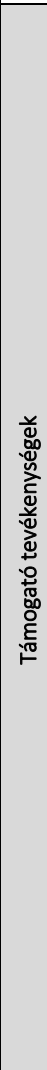 } & $\begin{array}{l}\text { Irányitás } \\
\text { (ANEF 6) }\end{array}$ & $\begin{array}{l}\text { Public Health England, Fa- } \\
\text { culty of Public Health, Asso- } \\
\text { ciation of Directors of Pub- } \\
\text { lic Health, Cary Quality } \\
\text { Commission, National Insti- } \\
\text { tute of Care Excellence }\end{array}$ & \begin{tabular}{|c} 
Federal Government, De- \\
partment of Health and Hu- \\
man Services, Office of the \\
Assistant Secretary for He- \\
alth, Office of Disease, Pre- \\
vention and Health Promo- \\
tion, US Preventive Task \\
Force, National Prevention \\
Council, Prevention Advi- \\
sory Group, Center for \\
Disease Control and Pre- \\
vention, Office for State, \\
Tribal, Local, and Territorial \\
Support, National Associa- \\
tion of County and City He- \\
alth Officials, National Insti-- \\
tutes of Health, Food and \\
Drug Administration, \\
Substance Abuse and \\
Mental Health Services Ad- \\
ministration, \\
State Government, State \\
Health Departments, \\
Local Health Departments
\end{tabular} & \begin{tabular}{|l} 
Ministry of Health, Welfare \\
and Sport, Council for Pub- \\
lic Health and Health Care, \\
Council for Public Health \\
and Society, National Insti- \\
tute for Public Health and \\
the Environment, Centre \\
for Healthy Living, Nether- \\
lands Organisation for He- \\
alth Research and Develop- \\
ment, Community Health \\
Services
\end{tabular} & $\begin{array}{c}\text { Health Canada, Minister of } \\
\text { Health, Chief Public Health } \\
\text { Officer, Public Health } \\
\text { Agency of Canada, Ca- } \\
\text { nadian Food Inspection } \\
\text { Agency, Conference of } \\
\text { F/P/T Ministers and Deputy } \\
\text { Ministers of Health, Board } \\
\text { of Health Council, } \\
\text { Ministry of Health and Long } \\
\text { Term Care }\end{array}$ & $\begin{array}{l}\text { Ministry of Health and He- } \\
\text { alth Care Serives, } \\
\text { County Municipalities, Part- } \\
\text { nership Forum, Local Muni- } \\
\text { cipalities }\end{array}$ & \begin{tabular}{|c|} 
Ministry of Health, National \\
Institute of Public Health \\
Surveillance and Health \\
Promotion, National Centre \\
for Disease, Prevention and \\
Control, National Health \\
Council, \\
Regional Government, \\
Agency for Regional Health \\
Services
\end{tabular} & \begin{tabular}{|c|} 
Central Government, Mi- \\
nister of Health, Ministry of \\
Health, Other ministerial \\
advisory committees, He- \\
alth Promotion Agency
\end{tabular} & \begin{tabular}{|c|} 
Emberi Eröforrások Minisz- \\
tériuma, Országos Köz- \\
egézzségügyi Intézet, \\
Egészségügyi Szakmai Kol- \\
légium
\end{tabular} \\
\hline & $\begin{array}{l}\text { Humán-eröfor- } \\
\text { rás (ANEF 7) }\end{array}$ & $\begin{array}{c}\text { Public Health England, NHS } \\
\text { England, Association of Di- } \\
\text { rectors of Public Health, } \\
\text { Universities }\end{array}$ & $\begin{array}{c}\text { Agency for Healthcare Re- } \\
\text { search and Quality, Center } \\
\text { for Disease Control an Pre- } \\
\text { vention, National Associa- } \\
\text { tion of County and City He- } \\
\text { alth Officials, Universities: } \\
\text { Yale University, Stanford } \\
\text { University, Columbia Uni- } \\
\text { versity, University of Michi- } \\
\text { gan, } \\
\text { State Health Departments, } \\
\text { Local Health Departments }\end{array}$ & $\begin{array}{c}\text { Dutch Association for Pre- } \\
\text { vention and Health Promo- } \\
\text { tion, Utrecht University, } \\
\text { Vrje University Amsterdam, } \\
\text { Maastricht University }\end{array}$ & $\begin{array}{c}\text { Public Health Agency of Ca- } \\
\text { nada, National Collabo- } \\
\text { rating Centers for Public } \\
\text { Health, Canadian Public He- } \\
\text { alth Association, University } \\
\text { of Biristh Columbia, } \\
\text { McMaster University, McG- } \\
\text { ill University, University of } \\
\text { Victoria, University of Wes- } \\
\text { tern Ontario, } \\
\text { Public Health Ontario }\end{array}$ & $\begin{array}{c}\text { Arctic University of Nor- } \\
\text { way, University of Bergen, } \\
\text { University of Oslo, National } \\
\text { Institute of Occupational } \\
\text { Health, } \\
\text { County Municipalities }\end{array}$ & \begin{tabular}{|c|} 
National Institute of He- \\
alth, National Health Coun- \\
cil, University of Siena, Sa- \\
pienza university of Rome
\end{tabular} & $\begin{array}{l}\text { Health Workforce New Ze- } \\
\text { aland, Universities }\end{array}$ & $\begin{array}{c}\text { Egyetemek, Népegészség- } \\
\text { ügyi Képző és Kutatóhelyek } \\
\text { Egyesülete, Népegészség- } \\
\text { ügyi Tudományos Társaság, } \\
\text { Magyar Higiénikusok Társa- } \\
\text { sága }\end{array}$ \\
\hline
\end{tabular}




\begin{tabular}{|c|c|c|c|c|c|c|c|c|}
\hline $\begin{array}{l}\text { Finanszírozás } \\
\text { (ANEF 8) }\end{array}$ & $\begin{array}{l}\text { Public Health England, NHS } \\
\text { England, Association of Di- } \\
\text { rectors of Public Health, } \\
\text { Carey Quality Commission, } \\
\text { Health Watch }\end{array}$ & $\begin{array}{c}\text { Federal Government, De- } \\
\text { partment of Health and Hu- } \\
\text { man Services, Office of the } \\
\text { Assistant Secretary for He- } \\
\text { alth, Office of Disease Pre- } \\
\text { vention and Health Promo- } \\
\text { tion, Center for Disease } \\
\text { Prevention and Health } \\
\text { Promotion - Office for } \\
\text { State, Tribal, Local, and } \\
\text { Territorial Support, } \\
\text { State Government, State } \\
\text { Health Departments } \\
\text { National Association of } \\
\text { County and City Health Of- } \\
\text { ficials, } \\
\text { Local Health Departments }\end{array}$ & $\begin{array}{l}\text { Ministry of Health, Ministry } \\
\text { of Finance, Tax and Cus- } \\
\text { toms Administration, Mi- } \\
\text { nistry of Social Welfare and } \\
\text { Employment, Ministry of } \\
\text { Economic Affairs, Ministry } \\
\text { of Economic Affairs, Natio- } \\
\text { nal Health Care Institute, } \\
\text { Dutch Competition } \\
\text { Authority, Dutch Health } \\
\text { Care Authority, Health Care } \\
\text { Inspectorate, Institutions } \\
\text { focusing on Health Promo- } \\
\text { tion, Netherlands Organisa- } \\
\text { tion for Health Research } \\
\text { and Development, Dutch } \\
\text { Organization for Scientific } \\
\text { Research, } \\
\text { Local municipalities }\end{array}$ & $\begin{array}{l}\text { Health Canada, Minister of } \\
\text { Health, Chief Public Health } \\
\text { Officer, Public Health } \\
\text { Agency of Canada, National } \\
\text { Collaborating Centers for } \\
\text { Public Health, Conference } \\
\text { of F/P/T Ministers and De- } \\
\text { puty Ministers of Health, } \\
\text { Ministry of Health and Long } \\
\text { Term Care }\end{array}$ & $\begin{array}{c}\text { Ministry of Health and He- } \\
\text { alth Care Serives, Di- } \\
\text { rectorate for Health, Nor- } \\
\text { wegian Board of Health Su- } \\
\text { pervision, } \\
\text { Regional Health Authority, } \\
\text { County Municipalities, } \\
\text { Local Municipalities }\end{array}$ & $\begin{array}{l}\text { Ministry of Health, National } \\
\text { Agency for Regional Health } \\
\text { Service, } \\
\text { Regional Government,Regi- } \\
\text { onal Health Department }\end{array}$ & $\begin{array}{l}\text { National Health Board, Ca- } \\
\text { pital Investment Commitee }\end{array}$ & $\begin{array}{c}\text { Nemzeti Egészzégbiztosí- } \\
\text { tási Alapkezelö, Emberi } \\
\text { Erő́források Miniszzériuma, } \\
\text { Állami Egészségügyi Ellátoó } \\
\text { Központ, } \\
\text { Önkormányzatok }\end{array}$ \\
\hline $\begin{array}{l}\text { Kommunikáció } \\
\text { (ANEF 9) }\end{array}$ & $\begin{array}{c}\text { Public Health England, He- } \\
\text { alth Watch, Association of } \\
\text { Directors of Public Health, } \\
\text { Local Government Associa- } \\
\text { tion, Royal Society of Public } \\
\text { Health, Public Health Net- } \\
\text { work, } \\
\text { Public Health England, } \\
\text { Health Watch, Local } \\
\text { Government Association }\end{array}$ & $\begin{array}{c}\text { Center for Disease Control } \\
\text { an Prevention, Food and } \\
\text { Drug Administration, } \\
\text { Substance Abuse and } \\
\text { Mental Health Administra- } \\
\text { tion, National Association } \\
\text { of Country and City Health } \\
\text { Officials, } \\
\text { Local Health Department }\end{array}$ & $\begin{array}{l}\text { Centre for Healthy Living, } \\
\text { Dutch Association for Pre- } \\
\text { vention and Health Promo- } \\
\text { tion, Collaborating Health } \\
\text { Funds, } \\
\text { Community Health Services }\end{array}$ & $\begin{array}{c}\text { Health Canada, Chief Public } \\
\text { Health Officer, Public He- } \\
\text { alth Agency of Canada, Ca- } \\
\text { nadian Public Health Asso- } \\
\text { ciation, } \\
\text { Office of the Chief Medical } \\
\text { Officer of Health, } \\
\text { Public Health Ontario }\end{array}$ & $\begin{array}{l}\text { Directorate for Health, } \\
\text { County Municipalities, } \\
\text { Local Municipalities, Health } \\
\text { Clinics, Healthy Life Centers }\end{array}$ & $\begin{array}{l}\text { Ministry of Health, National } \\
\text { Health Council, National } \\
\text { Institute of Health }\end{array}$ & $\begin{array}{c}\text { District Health Boards, } \\
\text { Voluntary services, Com- } \\
\text { munity Services }\end{array}$ & $\begin{array}{c}\text { Emberi Eróforrások Minisz- } \\
\text { tériuma, Országos Köz- } \\
\text { egészségügyi Intézet, Or- } \\
\text { szágos Gyógyszerészeti és } \\
\text { Élelemezés-egészségügyi In- } \\
\text { tézet, (TUDTÁRSOK) Ma- } \\
\text { gyar Dietetikusok Országos } \\
\text { Szövetsége, Magyar Védö- } \\
\text { nők Egyesülete, Magyar Hi- } \\
\text { giénikusok Társasága, } \\
\text { Egészségfejlesztési Iroda }\end{array}$ \\
\hline $\begin{array}{l}\text { Kutatás } \\
\text { (ANEF 10) }\end{array}$ & $\begin{array}{l}\text { Public Health England, Fa- } \\
\text { culty of Public Health, Soci- } \\
\text { ety for Social Medicine, As- } \\
\text { sociation of Directors of } \\
\text { Public Health, The Health } \\
\text { Foundation, Universities }\end{array}$ & $\begin{array}{c}\text { Agency for Healthcare Re- } \\
\text { search and Quality, Natio- } \\
\text { nal Institutes of Health- } \\
\text { National Cancer Institute, } \\
\text { National Institute of Aging, } \\
\text { National Institute on Al- } \\
\text { cohol Abuse and Alcoho- } \\
\text { lism, National Institute of } \\
\text { Enviromental Sciences, Na- } \\
\text { tional Institute of Minority } \\
\text { Health and Health Dispari- } \\
\text { ties Center for Disease } \\
\text { Control an Prevention, } \\
\text { Food and Drug Administra- } \\
\text { tion, Substance Abuse and } \\
\text { Mental Health Administra- } \\
\text { tion, Universities, National } \\
\text { Association of Country and } \\
\text { City Health Officials, } \\
\text { Local Health Departments }\end{array}$ & $\begin{array}{l}\text { Institutions focusing on he- } \\
\text { alth promotion, National } \\
\text { Institute for Public Health } \\
\text { and the Environment, } \\
\text { Centre for Healthy Living, } \\
\text { Netherlands Organisation } \\
\text { for Health Research and } \\
\text { Development, Dutch Orga- } \\
\text { nization for Scientific Rese- } \\
\text { arch, Statistics Nether- } \\
\text { lands, Netherlands Centre } \\
\text { for Occupational Diseases, } \\
\text { Utrecht University, Vrje } \\
\text { University Amsterdam, } \\
\text { Maastricht University, Ams- } \\
\text { terdam Medical Research, } \\
\text { Adademic Communy Cent- } \\
\text { res, Disease Specific Funds, } \\
\text { Community Health Services }\end{array}$ & $\begin{array}{c}\text { Health Canada, Statistics } \\
\text { Canada, Canadian Institu- } \\
\text { tes for Health Research, } \\
\text { National Collaborating Cen- } \\
\text { ters for Public Health, Ca- } \\
\text { nadian Public Health Asso- } \\
\text { ciation, } \\
\text { Public Health Ontario }\end{array}$ & $\begin{array}{c}\text { Directorate for Health, Nor- } \\
\text { wegian Institute of Public } \\
\text { Health } \\
\text { Statistics Norway, Norwe- } \\
\text { gian Knowledge Centre for } \\
\text { Health Services, National } \\
\text { Institute of Occupational } \\
\text { Health, Norwegian Food } \\
\text { Safety Authority, Norwe- } \\
\text { gian Institute of Public He- } \\
\text { alth }\end{array}$ & $\begin{array}{l}\text { National Institute of He- } \\
\text { alth, National Institute of } \\
\text { Public Health Surveillance } \\
\text { and Health Promotion, Na- } \\
\text { tional Agency for Regional } \\
\text { Health Services }\end{array}$ & $\begin{array}{l}\text { IT Health Board, Health Re- } \\
\text { search Council of New Ze- } \\
\text { aland, National Health } \\
\text { Committee, Health Promo- } \\
\text { tion Agency, Institute of } \\
\text { Environmental Science and } \\
\text { Research, Laboratories }\end{array}$ & 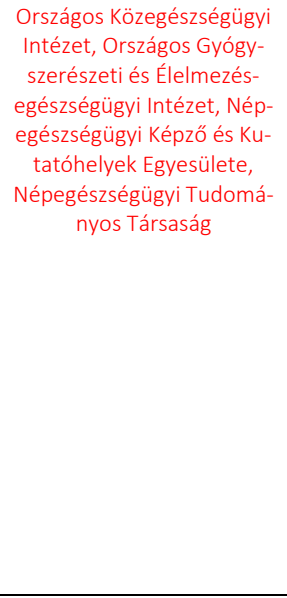 \\
\hline
\end{tabular}


HIVATKOZÁSOK

${ }^{1}$ World Health Organization. The 10 Essential Public Health Operations http://www.euro.who.int/en/health-topics/Health-systems/public-health-services/policy/the-10-essential-public-health-operations Elérve: 2018. 03. 11. 